\title{
TITLE:
}

\section{Ionic Liquid Fluorohydrogenates and Their Applications}

\section{$\operatorname{AUTHOR}(\mathrm{S}):$}

Hagiwara, Rika; Nohira, Toshiyuki; Shimada, Takashi; Fujinaga, Takashi; Konno, Soichiro; Tsuda, Tetsuya

\section{CITATION:}

Hagiwara, Rika ... [et al]. Ionic Liquid Fluorohydrogenates and Their Applications. ECS Transactions 2006, 3(35): 187-193

\section{ISSUE DATE:}

2006

URL:

http://hdl.handle.net/2433/260946

\section{RIGHT:}

This is the Accepted Manuscript version of an article accepted for publication in ECS Transactions. The Electrochemical Society and IOP Publishing Ltd are not responsible for any errors or omissions in this version of the manuscript or any version derived from it. The Version of Record is available online at https://doi.org/10.1149/1.2798661.; この論文は出版 社版でありません。引用の際には出版社版をご確認ご利用ください。; This is not the published version. Please cite only the published version. 


\section{Ionic Liquid Fluorohydrogenates and Their Applications}

Rika Hagiwara, Toshiyuki Nohira, Takashi Shimada, Takashi Fujinaga, Soichiro Konno, Tetsuya Tsuda

Graduate School of Energy Science, Kyoto University

Sakyo-ku, Kyoto 606-8501, Japan

The recent results are described on the developments of ionic liquid (IL) fluorohydrogenates with high ionic conductivities and wide electrochemical windows. Several cyclic ammonium cations have been found to be combined with fluorohydrogenate anions giving a vacuum stable ionic liquid fluorohydrogenates, $\mathrm{Cat}^{+}\left[(\mathrm{FH})_{2.3} \mathrm{~F}\right]^{-} . \quad N-$ ethyl- $N$-methylpyrrolidinium fluorohydrogenate, EMPyrro $(\mathrm{FH})_{2.3} \mathrm{~F}$, and $\mathrm{N}$-allylpyridinium fluorohydrogenate, APyrid(FH) ${ }_{2.3} \mathrm{~F}$, exhibit wide electrochemical windows compared to the other fluorohydrogenates. A fluorohydrogenate fuel cell (FHFC) using HF-deficient IL, 1-ethyl-3-methyl-imidazolium fluorohydrogenate, $\operatorname{EMIm}(\mathrm{FH})_{1.3} \mathrm{~F}$, as the electrolyte operates at $120^{\circ} \mathrm{C}$ without humidification. The maximum output power so far obtained in the preliminary cell test is $41 \mathrm{mWcm}^{-2}\left(0.41 \mathrm{~V}\right.$ and $\left.100 \mathrm{~mA} \mathrm{~cm}^{-2}\right)$ at $40^{\circ} \mathrm{C}$ without humidification.

\section{New cations for ionic liquid fluorohydrogenates, $\mathrm{Cat}^{+}\left[(\mathbf{F H})_{2.3} \mathrm{~F}\right]^{-}$}

We have recently found that, in addition to imidazolium cations, some quaternary ammonium cations shown in Fig. 1 form vacuum stable room temperature ionic liquid (IL) fluorohydrogenates, $\mathrm{Cat}^{+}\left[(\mathrm{FH})_{2.3} \mathrm{~F}\right]^{-}$. These salts possess high conductivity and excellent stability at ambient conditions. They are all heterocyclic cations combined with

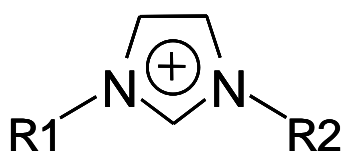

(a)<smiles>[R2][N+]1([R7])CCCC1</smiles>

(c)<smiles></smiles>

(b)<smiles>[R][N+]1([R])CCCCC1</smiles>

(d)<smiles>[R2][N+]1([R])CCOCC1</smiles>

(e)

Figure 1. Cations combined with fluorohydrogenate anions to form ionic liquid $\begin{array}{lll}\text { fluorohydrogenates. (a)1,3-dialkylimidazolium, (b) } N \text {-alkylpyridinium, } & \text { (c) } N, N \text { - }\end{array}$ dialkylpyrrolidinium, (d) $N, N$-dialkylpiperidinium, (e) $N, N$-dialkylmorphornium. 
fluorohydrogenate anions. All of them exhibit the same vacuum stable composition, $\mathrm{Cat}^{+}\left[(\mathrm{FH})_{2.3} \mathrm{~F}\right]^{-}$, at room temperature regardless of the type of the cation. The non-integer figure of 2.3 occurring in the formula is due to the mixing of two types of fluorohydrogenate anions, $\left[(\mathrm{FH})_{2} \mathrm{~F}\right]^{-}$and $\left[(\mathrm{FH})_{3} \mathrm{~F}\right]^{-}(1-3)$.

A high conductivity of $100 \mathrm{mS} \mathrm{cm}$ is found for 1-ethyl-3-methylimidazolium fluorohydrogenates (1). The electrochemical window of the salt is approximately $3 \mathrm{~V}$, not wide enough for application to advanced capacitors (4). As a result of systematic survey of cations, we have found some ammonium cations that exhibit superior electrochemical stability without losing conductivities when they are combined with fluorohydrogenate anions (Table 1). Among the ionic liquid fluorohydrogenates synthesized so far, $N$-ethyl$N$-methylpyrrolidinium fluorohydrogenates, EMPyrro $(\mathrm{FH})_{2.3} \mathrm{~F}$, and $N$-allylpyridinium fluorohydrogenate, $\operatorname{APyrid}(\mathrm{FH})_{2.3} \mathrm{~F}$, exhibit wide electrochemical windows compared to the other fluorohydrogenates as well as high ionic conductivities of around $80 \mathrm{mScm}^{-}$ ${ }^{1}(2,3)$.

\section{Fluorohydrogenate fuel cells operating at middle-ranged temperatures without humidification}

One of the unique applications of the IL fluorohydrogenates is the electrolyte for a fuel cell operating at middle-ranged temperatures $\left(100-150^{\circ} \mathrm{C}\right)$ without humidification of the

TABLE 1 Some physical properties of ionic liquid fluorohydrognates*.

\begin{tabular}{|c|c|c|c|}
\hline IL fluorohydrogenates & $\begin{array}{l}\text { Density } \\
d / \mathrm{g} \mathrm{cm}^{-3}\end{array}$ & $\begin{array}{l}\text { Viscosity } \\
\eta / \mathrm{cP}\end{array}$ & $\begin{array}{l}\text { Conductivity } \\
\sigma / \mathrm{mScm}^{-1}\end{array}$ \\
\hline $\operatorname{DMIm}(\mathrm{FH})_{2.3} \mathrm{~F}$ & 1.17 & 5.1 & 110 \\
\hline $\mathrm{EMIm}(\mathrm{FH})_{2.3} \mathrm{~F}$ & 1.13 & 4.9 & 100 \\
\hline $\operatorname{AMIm}(\mathrm{FH})_{2.3} \mathrm{~F}$ & 1.11 & 5.5 & 90 \\
\hline $\operatorname{PrMIm}(\mathrm{FH})_{2.3} \mathrm{~F}$ & 1.11 & 7.0 & 61 \\
\hline $\mathrm{BMIm}(\mathrm{FH})_{2.3} \mathrm{~F}$ & 1.08 & 19.6 & 33 \\
\hline $\operatorname{PeMIm}(\mathrm{FH})_{2.3} \mathrm{~F}$ & 1.05 & 26.7 & 27 \\
\hline $\operatorname{HMIm}(\mathrm{FH})_{2.3} \mathrm{~F}$ & 1.00 & 25.8 & 16 \\
\hline AMPyrro $(\mathrm{FH})_{2.3} \mathrm{~F}$ & 1.05 & 8.5 & 78 \\
\hline $\operatorname{EMPyrro}(\mathrm{FH})_{2.3} \mathrm{~F}$ & 1.07 & 9.9 & 74.6 \\
\hline PrMPyrro $(\mathrm{FH})_{2.3} \mathrm{~F}$ & 1.05 & 11.2 & 58.1 \\
\hline $\operatorname{BMPyrro}(\mathrm{FH})_{2.3} \mathrm{~F}$ & 1.04 & 14.5 & 35.9 \\
\hline HeMPyrro(FH) $)_{2.3} \mathrm{~F}$ & 0.993 & 18.0 & 23.7 \\
\hline $\operatorname{AMPip}(\mathrm{FH})_{2.3} \mathrm{~F}$ & 1.06 & 16.7 & 63 \\
\hline $\operatorname{EMPip}(\mathrm{FH})_{2.3} \mathrm{~F}$ & 1.07 & 24.2 & 37.2 \\
\hline $\operatorname{PrMPip}(\mathrm{FH})_{2.3} \mathrm{~F}$ & 1.06 & 33.0 & 23.9 \\
\hline $\operatorname{BMPip}(\mathrm{FH})_{2.3} \mathrm{~F}$ & 1.04 & 37.1 & 12.3 \\
\hline $\operatorname{APyrid}(\mathrm{FH})_{2.3} \mathrm{~F}$ & 1.12 & 5.3 & 82 \\
\hline $\operatorname{BPyrid}(\mathrm{FH})_{2.3} \mathrm{~F}$ & 1.09 & 25.0 & 37 \\
\hline AMMor(FH $)_{2.3} \mathrm{~F}$ & 1.16 & 34.6 & 35 \\
\hline
\end{tabular}

*At 298K. Abbrev.; Im:imidazolium, Pyrro: pyrrolidinium, Pip: piperidinium, Pyrid: pyridinium, Mor: morphornium, DM: dimethyl, E: ethyl, M: methyl, Pr: propyl, B: butyl, Pe: pentyl, H: hexyl, A: allyl. 
electrolyte (5), taking advantage of their non-volatile nature and high conductivity in addition to the ability of proton transport via the fluorohydrogenate anions. HF-deficient and thermally more stable ionic liquid fluorohydrogenate, $\mathrm{EMIm}(\mathrm{FH})_{1.3} \mathrm{~F}(6)$, is applied for the cell operation at more than $100^{\circ} \mathrm{C}$ (Fig. 2). The cell operation has been confirmed using a neat fluorohydrogenate as a liquid electrolyte. The conceivable electrode reactions are as follows.

$$
\begin{aligned}
& \text { Anode }: \mathrm{H}_{2}+6 \mathrm{FHF}^{-} \rightarrow 4\left[(\mathrm{FH})_{2} \mathrm{~F}\right]^{-}+2 \mathrm{e} \\
& \text { Cathode }: 1 / 2 \mathrm{O}_{2}+4\left[(\mathrm{FH})_{2} \mathrm{~F}\right]^{-}+2 \mathrm{e} \rightarrow \mathrm{H}_{2} \mathrm{O}+6 \mathrm{FHF}^{-} \\
& \text {Total }: \mathrm{H}_{2}+1 / 2 \mathrm{O}_{2} \rightarrow \mathrm{H}_{2} \mathrm{O}
\end{aligned}
$$

For practical operation of the cell, the IL is immobilized in a polymer matrix that is sandwiched between the gas diffusion electrodes to form a membrane-electrode assembly (MEA). Fluorohydrogenates are mixed with some monomers (7) or polymers dissolved in some organic solvents (8) and the composites are formed by polymerization or elimination of the organic solvents. In the present study, hydroxylethyl methacrylate (HEMA) was used as a monomer to be mixed with the IL. Figure 3 shows the ionic conductivities of the composites under dry hydrogen atmosphere. The conductivity of the neat IL-HEMA polymer composite fixed in a porous PTFE membrane (thickness: $80 \mu \mathrm{m}$, vacancy ratio: $80 \%$, diameter: $0.45 \mu \mathrm{m}$ ) is decreased with the increase of the polymer content in the membrane. The ionic conductivity of the composite made from the equimolar mixture of the IL and HEMA monomer exhibits $45 \mathrm{mS} \mathrm{cm}^{-1}$ at $120^{\circ} \mathrm{C}$. Figure 4 shows a TG curve of the IL-HEMA polymer composite (5:5) fixed in the PTFE membrane. The weight decrease at around $270^{\circ} \mathrm{C}$ is ascribed to the thermal decomposition of the IL. A slight weight decrease found in the temperature range of 100 to $200^{\circ} \mathrm{C}$ is mostly ascribed to the water elimination from the composite. Partial decomposition of the anions of the IL would contribute to the weight loss but not for the temperatures of lower than $130^{\circ} \mathrm{C}$ since the $\operatorname{EMIm}(\mathrm{FH})_{1.3} \mathrm{~F}$ is prepared by thermal decomposition of $\mathrm{EMIm}(\mathrm{FH})_{2.3} \mathrm{~F}$ at $130^{\circ} \mathrm{C}$ and stable at this temperature.

Usually the liquid mixture is soaked in a porous plastic film before polymerization

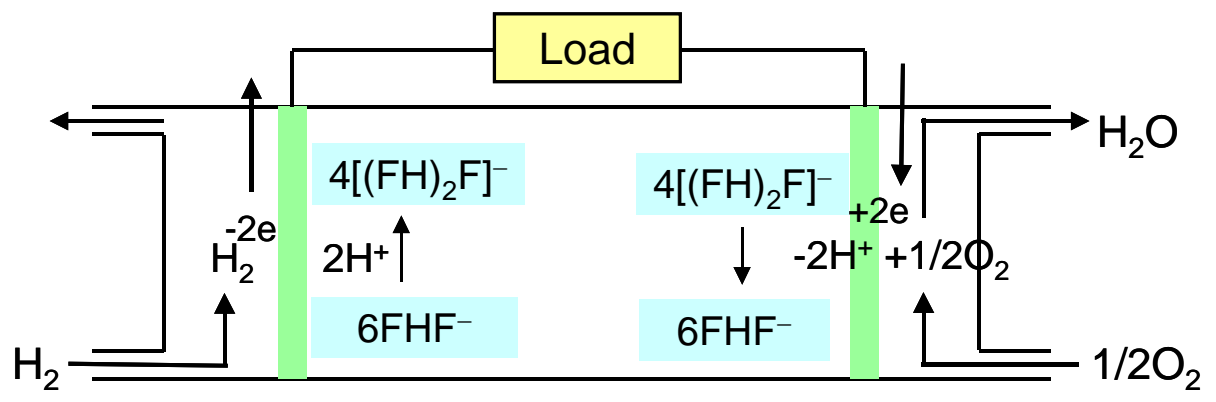

Anode $: \mathrm{H}_{2}+6 \mathrm{FHF}^{-} \rightarrow 4\left[(\mathrm{FH})_{2} \mathrm{~F}\right]^{-}+2 \mathrm{e}$

Cathode : $1 / 2 \mathrm{O}_{2}+4\left[(\mathrm{FH})_{2} \mathrm{~F}\right]^{-}+2 \mathrm{e} \rightarrow \mathrm{H}_{2} \mathrm{O}+6 \mathrm{FHF}^{-}$

Total $: \mathrm{H}_{2}+1 / 2 \mathrm{O}_{2} \rightarrow \mathrm{H}_{2} \mathrm{O}$ 
Figure 2. Fluorohydrogenate fuel cell (FHFC). The electrode reactions described are for $\operatorname{EMIm}(\mathrm{FH})_{1.3} \mathrm{~F}$ in which the major anionic species are $\mathrm{FHF}^{-}$and $\left[(\mathrm{FH})_{2} \mathrm{~F}\right]^{-}$.

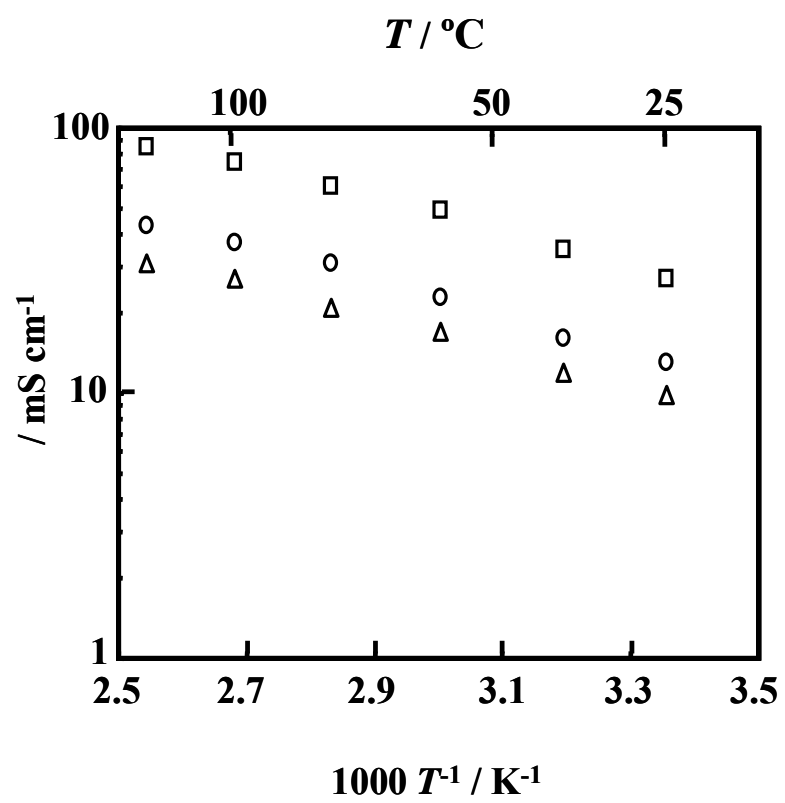

Figure 3. Ionic conductivity of EMIm $(\mathrm{FH})_{1.3} \mathrm{~F}$-HEMA composite fixed in a porous PTFE membrane (Thickness: $80 \mu \mathrm{m}$, Vacancy ratio: $80 \%$, diameter: $0.45 \mu \mathrm{m}$ ). $\square$ : neat $\operatorname{EMIm}(\mathrm{FH})_{2.3} \mathrm{~F}, \mathrm{O}: 5: 5, \triangle: 4: 6$ in molar ratio.

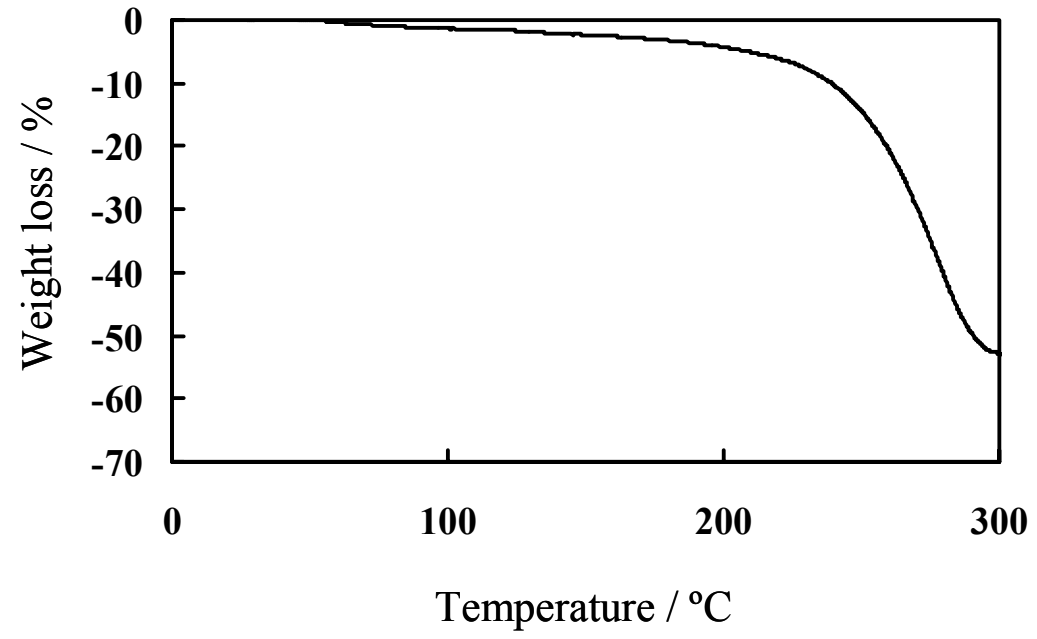

Figure 4. TG curve of EMIm(FH) ${ }_{1.3}$ F-PolyHEMA (5:5) composite membrane on GDE

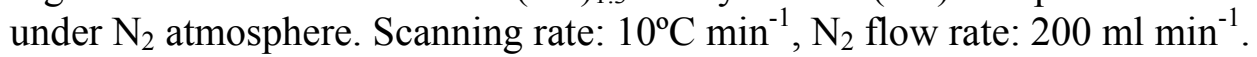

in order to provide enough mechanical strength to the composite membranes. The membrane is sandwiched between the gas diffusion electrodes (GDE, E-TEK, ELAT ${ }^{\circledR}$ ) with a geometrical surface area of $5 \mathrm{~cm}^{2}$. Pt catalyst of $5.0 \mathrm{mg} \mathrm{cm}^{-2}$ for both the $\mathrm{H}_{2}$ anode 
and $\mathrm{O}_{2}$ cathode is fixed on the GDE without using Nafion ${ }^{\circledR}$ glue. Figure 5 shows a schematic illustration of the test cell. The separators are carbon blocks with serpentine flow channels. The cell is equipped with a reference hydrogen electrode made of a platinum wire that is placed in the hydrogen flow channel, the tip contacting the electrolyte membrane.

Figures 6 and 7 show I-V (diamond) and I-P plots (circle) of the cell operating at $40^{\circ} \mathrm{C}$

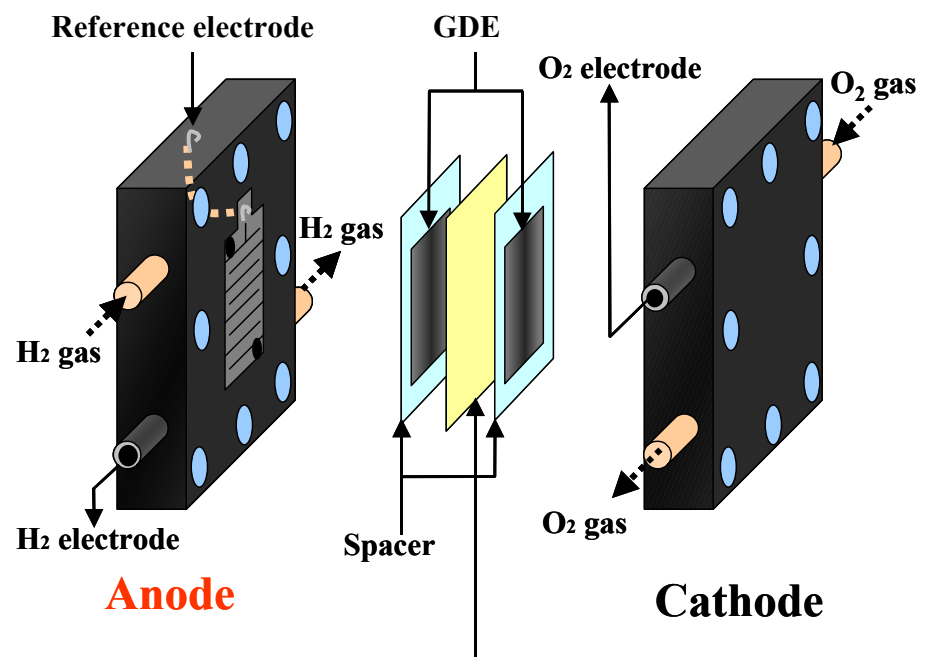

Electrolyte membrane

Figure 5. A schematic illustration of the test cell.

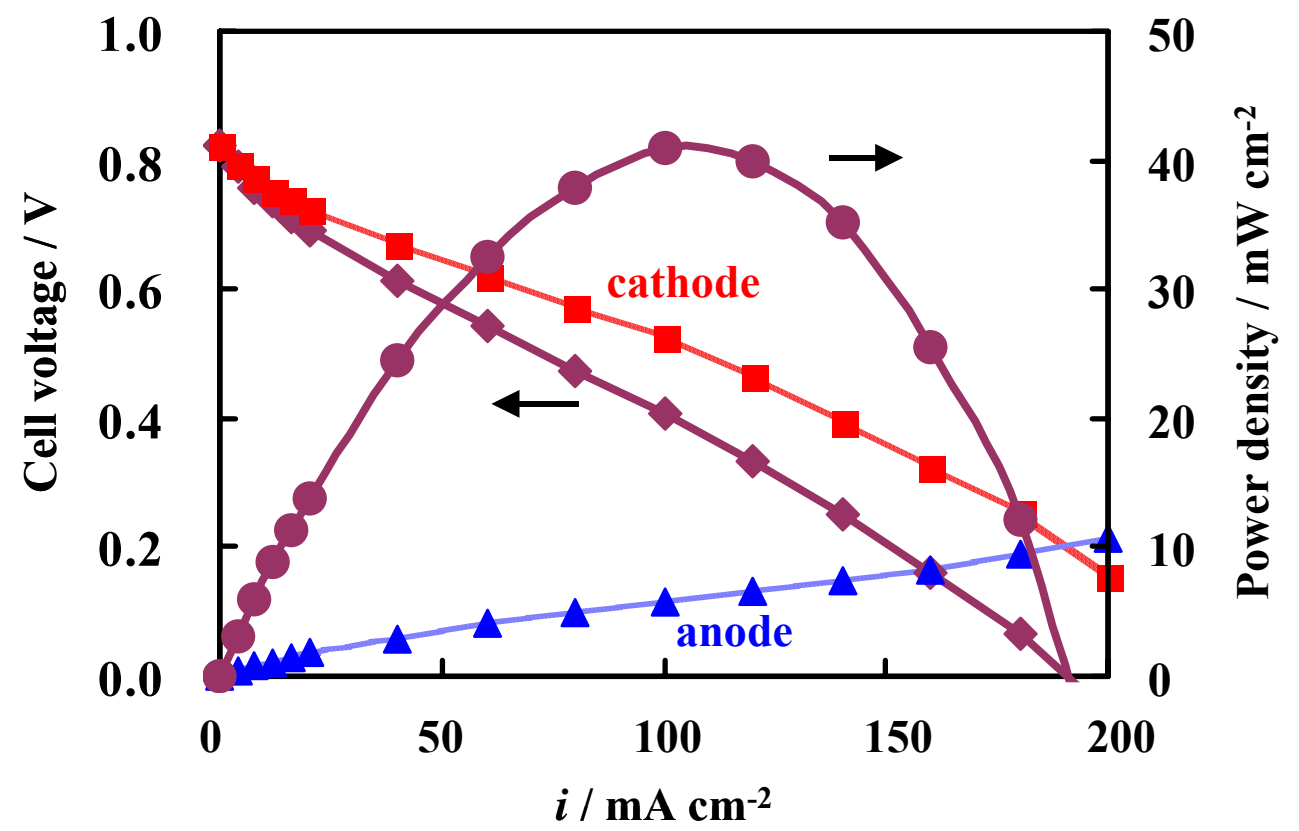


Figure 6. I-V and I-P plots of FHFC operating at $40^{\circ} \mathrm{C}$ without humidification. $\mathrm{H}_{2}$ and $\mathrm{O}_{2}$ flow rate: $25 \mathrm{ml} \mathrm{min}{ }^{-1}$. $\operatorname{EMIm}(\mathrm{FH})_{1.3} \mathrm{~F}: 2$-hydrogxyethyl methacrylate $=1: 1$ (in molar ratio).

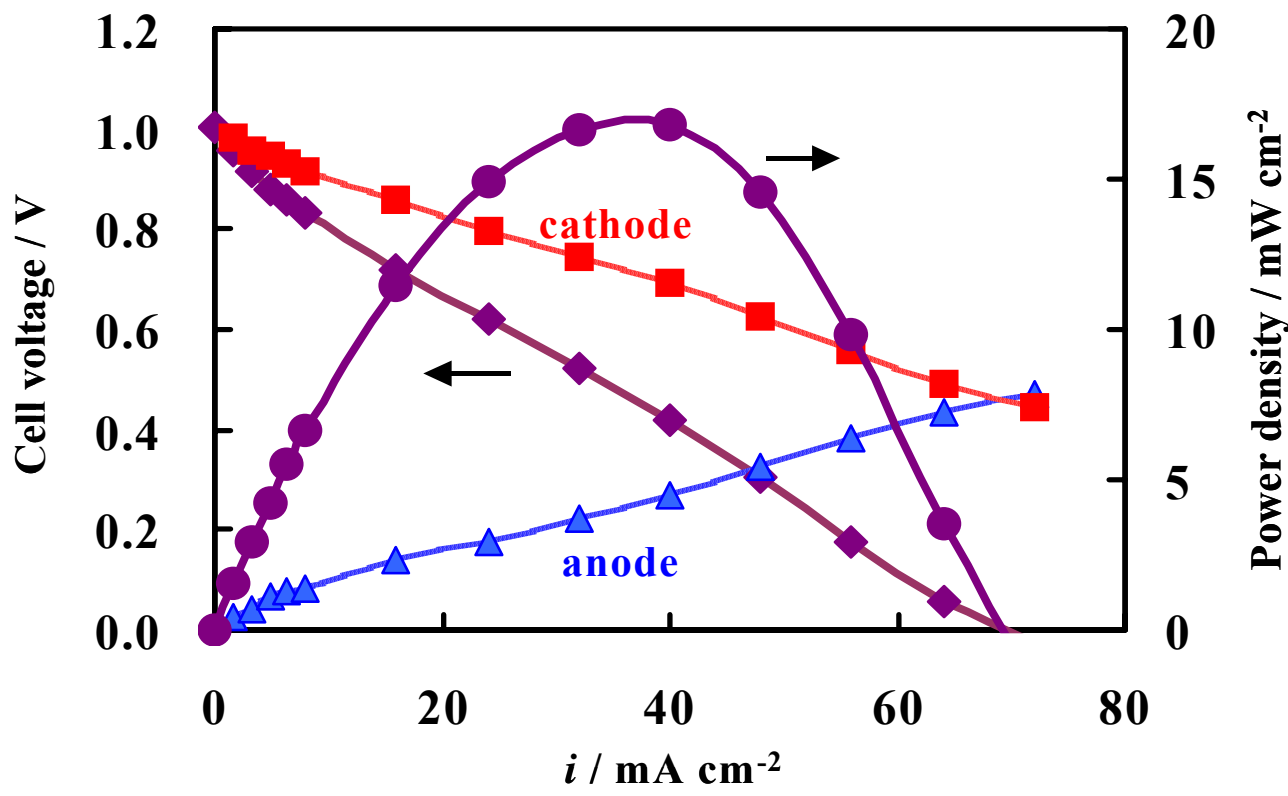

Figure. 7. I-V and I-P plots of FHFC operating at $120^{\circ} \mathrm{C}$ without humidification. $\mathrm{H}_{2}$ and $\mathrm{O}_{2}$ flow rate: $25 \mathrm{ml} \mathrm{min}^{-1}$. EMIm(FH) ${ }_{1.3} \mathrm{~F}: 2$-hydrogxyethyl methacrylate $=1: 1$ (in molar ratio).

$120^{\circ} \mathrm{C}$ without humidification, respectively. Plots of cathode (square) and anode (triangle) polarization measured against the reference hydrogen electrode are also included in the figures. The highest output power of $41 \mathrm{~mW} \mathrm{~cm}^{-2}$ was obtained $(0.41 \mathrm{~V}$ and $100 \mathrm{~mA} \mathrm{~cm}$ ) at $40^{\circ} \mathrm{C}$. In addition to the cathode overpotential, the anode overpotential of this fuel cell is fairly large compared to that found for the PEMFC anode. When the cell operated at $120^{\circ} \mathrm{C}$, both the cathode and anode overpotentials were increased to decrease the maximum output power down to $17 \mathrm{~mW} \mathrm{~cm}^{-2}(0.42 \mathrm{~V}$ and 40 $\mathrm{mA} \mathrm{cm}{ }^{-2}$ ). Especially the increase of the anode overpotential is significant compared to that of the cathode. As shown in eq. 1, the anode reaction of this FHFC is considered to involve the transformation of fluorohydrogenate anions with the reaction with hydrogen, which is different from the conventional PEMFC. However, the unexpected increases of the overpotentials of both the electrodes by the elevation of operation temperature found in the present study is presumably due to the decrease of the effective reaction interface between the membrane and GDE by the deformation of the polymer composite membrane. The search for thermally more stable polymer to be combined with the IL is necessary for further improvement of the cell performance of the FHFC. 


\section{Conclusions}

Ionic liquid fluorohydrogenates vacuum-stable at ambient temperature giving an identical composition, $\operatorname{Cat}(\mathrm{FH})_{2.3} \mathrm{~F}$, are formed by the combination with some cyclic onium cations. A wide electrochemical window of more than $4 \mathrm{~V}$ is realized by the choice of cation and the alkyl group on it. A fluorohydrogenate fuel cell (FHFC) operates at middle-ranged temperatures of more than $100^{\circ} \mathrm{C}$ under non-humidified conditions. Further developments of the polymer-IL composite electrolytes, gas diffusion electrodes and catalysts are necessary for the improvement of the cell performance.

\section{Acknowledgments}

A part of this work was supported by the Grant-in-Aid for Scientific Research in Priority Area "Science of Ionic Liquids" from Ministry of Education, Culture, Sports, Science and Technology. Another part of this work was supported by the New Energy Development Organization (NEDO) for the project "Strategic Development of PEFC Technologies for Practical Application-Development of Technology for Next-generation Fuel Cells."

\section{References}

1. R. Hagiwara, K. Matsumoto, "Novel Fluoride Anion Salts," in "Electrochemical Aspects of Ionic Liquids," H. Ohno ed., John Wiley \& Sons, Inc.,Chapt. 18, pp. 227 (2005), and references therein.

2. K. Matsumoto, R. Hagiwara, Y. Ito, Electrochem. Solid-State Lett., 7, E41 (2004).

3. S. Konno, R. Hagiwara, Abstracts of the $73^{\text {rd }}$ Annual meeting of Electrochemical Society, Japan, pp.141.

4. M. Ue, M. Takeda, A. Toriumi, A. Kominato, R. Hagiwara, Y. Ito, J. Electrochem. Soc., 150, No.4, A499 (2003).

5. R. Hagiwara, T. Nohira, K. Matsumoto, Y. Tamba, Electrochem. Solid-State Lett., 8, A231 (2005).

6. R. Hagiwara, K. Matsumoto, Y. Nakamori, T. Tsuda, Y. Ito, H. Matsumoto, K. Momota, J. Electrochem. Soc., 150, D195 (2003).

7. T. Tsuda, T. Nohira, Y. Nakamori, K. Matsumoto, R. Hagiwara and Y. Ito, Solid St. Ionics, 149, No. 3-4, 295-298 (2002).

8. Je.Seung Lee, T. Nohira, R. Hagiwara, ECS Transactions, "Proton Exchange Membrane Fuel Cells 6," T. Fuller, C. Bock, S. Cleghorn, H. Gasteiger, T. Jarvi, M. Mathias, M. Murthy, T. Nguyen, V. Ramani, E. Stuve, T. Zawodzinski Eds., 3(1), 5562 (2006). 